\title{
Dense Membrane Crystallization in gas-liquid systems: key parameters influencing fouling
}

Maïté MICHAUD, Denis MANGIN, Catherine CHARCOSSET, Elodie CHABANON ${ }^{*}$

Univ Lyon, Université Claude Bernard Lyon 1, CNRS, LAGEPP UMR 5007, 43 boulevard du 11 novembre 1918, F-69100, VILLEURBANNE,

France

Revised Article submitted to the

Industrial \& Engineering Chemistry Research - July 2019

*: Corresponding author

용: +33472431852

Email: elodie.chabanon@univ-lyon1.fr 


\section{ABSTRACT}

Membranes have been increasingly considered as a promising technology to conventional crystallization processes. One of the most significant benefits would be to control the supersaturation by fine tuning the mass transfer throughout the membrane. Several investigations on this topic have already been proposed using porous materials. However, numerous authors dealt with scaling phenomena with either pore blocking or surface fouling. To reduce this issue, the use of dense skin membranes seems to be an interesting alternative while keeping other membrane advantages. The present study aims at analyzing the potential of non-porous materials in membrane contactors used for crystallization purpose. More specifically two major scientific challenges are investigated at closely: how to avoid the membrane fouling by choosing appropriate membrane materials and to predict, potentially, the crystallization location in/on a dense polymeric material. The global aim of this study is to better understand the fouling mechanisms in dense membranes. Several commercially available materials are screened and experiments are conducted under strict diffusion regime in a gas-liquid system with a stagnant liquid phase at $20^{\circ} \mathrm{C}$. Impact of no-hydrodynamics parameters on the crystallization location is studied, namely: changes in gas flowrate, membrane thickness, polymer type, physical state and initial moisture. It is shown that the first major key parameter to be considered to prevent fouling is the surface energy of the material. Results obtained highlight that hydrophilic membranes such as cellulose acetate, are much more difficult to clean than hydrophobic membranes, such as FEP. This material property will impact the adherence of solid compound on the membrane. The permeability of all chemical reactants and their interaction with the membrane materials are the second key parameter to investigate carefully. Results obtained show that no crystals are present on the surface of hydrophobic and highly permeable polymers, such as polydimethylsiloxane (PDMS) or Teflon AF 2400; meanwhile, large amount of crystals are recovered in the solution. On the contrary, crystals are dropped off the membrane surface of hydrophobic but less permeable polymers like FEP, although the amount of crystals recovered in the solution compartment is at least 10 times lower by using FEP than PDMS or Teflon AF 2400. These two parameters have a crucial incidence on the solid deposit location in/on the membrane. In the context of this study, membrane fouling is expected to be avoided 
by using appropriate hydrophobic and highly permeable dense membranes such as Teflon AF 2400 and PDMS.

KEYWORDS:

Dense membranes, Crystallization, Fouling. 


\section{INTRODUCTION}

Intensified, continuous and easy to scale-up processes are part of the actual challenges, especially in crystallization/precipitation applications where the stirred reactor is the most implemented at the industrial scale ${ }^{1}$. Despite its robustness, the later suffers from macro/micromixing heterogeneities affecting both the production repeatability from batch to batch and the final homogeneity in the product characteristics ${ }^{2}$.

Among the different growing breakthrough technology candidates, membranes are considered as one of the most promising to overcome this issue ${ }^{3}$. Indeed, numerous publications about different membrane applications are available in the literature and there has been a significant increasing interest for specific crystallization/membrane processes during the last few years ${ }^{4-8}$. The combination of these two processes was reported, for the first time, in 1917 by Kober ${ }^{9}$ that unexpectedly observed the crystals apparition. But, it is only in 1986 that the performance of the crystallization by using a membrane was studied by Azoury et al. $^{10}$, who investigated reverse osmosis membranes for the precipitation of calcium oxalate. Since then, the range of membrane crystallizer processes has widened to other membrane contactors applications such as the well-known membrane distillation ${ }^{11-13}$. Membrane crystallizers aim at intensify mass transfer operations with perfect control of mixing conditions and can be applied with both gas-liquid ${ }^{14,15}$ and liquid-liquid ${ }^{15,16}$ systems. Supporting this concept, systematic merits are put forward in the different reviews on this topic, in addition to the easiest scale-up ability ${ }^{16}$. Firstly, it is commonly accepted that the additional mass transfer resistance induced by the membrane is well balanced by the large interfacial contact area developed. On the other hand, it is also highlighted that, the fine local control of both (i) hydrodynamics in the solution within the vicinity of the membrane and (ii) mass transfer throughout the membrane thickness is easily achievable in such technology ${ }^{4}$. As it is considered as a key parameter for the process efficiency and product quality ${ }^{17}$, the fine control of the mass transfer is truly an improvement of great matter especially for sectors with highadded-value products like in the pharmaceutical field. Well controlled crystallization using membranes has been proven several times by mastering the polymorph form as desired ${ }^{18,19}$. The other major advantage of such control over the supersaturation 
level within the membrane fiber volume is the resulting narrower crystal size distribution compared to the stirred tank reference.

Since the late 80's, porous membranes have been extensively studied in the literature $^{20}$ for diverse applications such as: water purification by membrane distillation ${ }^{13,21-23}$ or gas-liquid absorption for $\mathrm{CO}_{2}$ capture ${ }^{16,24,25} \ldots$ Porous membranes are subjected to fouling by both surface scaling and pore blocking by crystal formation ${ }^{15,26,27}$. According to the literature, the membrane roughness ${ }^{28}$ and the adhesion forces ${ }^{29}$ that can exist between the membrane and the solute, are influent parameters. The membrane chemistry is also to be considered ${ }^{30}$. For example, $\mathrm{Wu}$ et al. reported that carboxylic functional groups induce an increase of the absorption rate of alginate ${ }^{31}$.

But the fouling phenomenon is also influenced by the wetting issue and both are difficult to decouple ${ }^{27,32}$. The consequence of the fouling event is the decrease of the permeate flux through the membrane leading to drastic decrease in the process performances overtime. Despite a lot of research efforts, the occurrence of membrane fouling is still at this time a deadlock to make the membrane crystallization a reality at the industrial scale ${ }^{4}$ and the mechanisms governing this phenomenon remain unknown ${ }^{33}$. Recent development of slippery membrane materials has been proposed in the literature ${ }^{33,34}$. These materials are mainly microporous with a plasma surface treatment and are dedicated to membrane distillation applications. Xiao et al. ${ }^{33}$ assume that the surface treatment allows the development of gas layer between the solution and the polymer surface which would help to prevent membrane fouling.

In the case of this study, the use of dense membrane is investigated. Probably due to lower mass transfer rate, using dense membrane instead of microporous membrane for crystallization purposes has been scarcely proposed so far. Dense membranes are more commonly employed in gas separation or $\mathrm{CO}_{2}$ capture systems for instance $^{14,35}$. However using a sufficiently thin layer of dense membrane can lead to similar permeance values as with classical porous membranes ${ }^{36}$. Besides, implementing this type of membrane for crystallization applications, appears to be an interesting compromise between stability overtime and process performances, since the recurrent pore blocking issue would be circumvented while benefiting of the membrane process advantages. Indeed, although the formation of gas bubble on the 
membrane surface is unlikely to take place since the surface is not microporous, it is expected that this non porous surface state can reduce the risk of solid deposit inside and on the surface of the membrane.

However, some rare examples of intra-scaling in dense membranes have been addressed in the literature ${ }^{14,26,37}$. This intra-scaling might be linked to the polymer matrix and its morphology. But this phenomenon has not been more deeply studied since then, to our knowledge. Thus, it seems clear that fundamental studies on the risks and the causes of fouling are first needed to make proper choices of dense membrane materials for future crystallization applications. This is a complex subject, due to the multiple interplays between the crystal properties, the operating conditions and the membrane material characteristics ${ }^{4}$.

This study intends to address this scientific challenge by investigating dense membrane crystallization systems. Hence, from the analysis of the local phenomena explaining, how, where, why and when crystallization takes place in/on the polymer material, the study intends to develop a rational knowledge of the interactions between the crystals and the membrane only, without being influenced by hydrodynamics.

\section{MATERIALS AND METHODS}

In order to reach the aim of this study, the precipitation of a model compound, $\mathrm{BaCO}_{3}$, is investigated in gas-liquid $(\mathrm{G} / \mathrm{L})$ system using several dense membranes commercially available.

\section{Denses membranes}

The spectrum of dense membrane material candidates is extremely large and a series of solid permeable matrices has been selected, with different properties which are expected to have a significant influence on crystallization mechanism and location:

$\checkmark$ Hydrophilic and hydrophobic properties will strongly modify the water flux (water permeability in polymers ranges over 6 orders of magnitudes) and intramembrane water concentration. This is expected to affect the location of nucleation and crystallization through solubility product and supersaturation effects. The selected hydrophilic membrane (cf. Table 1) exhibits higer selectivity $\left(\alpha_{\mathrm{H}_{2} \mathrm{O} / \mathrm{CO}_{2}}=232-290\right.$ for $\left.\mathrm{CA}\right)$ than the hydrophobic membranes selected $\left(\alpha_{\mathrm{H}_{2} \mathrm{O} / \mathrm{CO}_{2}}=1.43\right.$ for Teflon AF 2400, 1.31 for FEP or 12.8 for PDMS). 
Then, the local supersaturation in the liquid phase close to the membrane surface will be highly increased by the water flux through the membrane and thus favour the fouling.

$\checkmark$ Hydrophilic and hydrophobic materials also differ in terms of surface energy, which is known to play a key role on adhesion effects ${ }^{38}$. The search for nonadhesive and membrane surface crystallization conditions is of primary importance to avoid fouling.

$\checkmark$ Mechanical resistance of the polymer is also likely to modify the nucleation and crystal formation kinetics. It has been shown that glassy polymers enable membrane surface crystallization, while a rubbery, low mechanical resistance polymer like polydimethylsiloxane (PDMS) leads to intra membrane crystallization ${ }^{14}$.

$\checkmark \mathrm{CO}_{2}$ and water permeabilities are straight responsible of the mass transfer through the membrane. Their influence on the crystallization location, in the membrane or at its surface, would strongly influence fouling phenomena.

Moreover, it might be interesting to evaluate an ion exchange material which combines selectivity towards ionic reactants, a high water permeability and large mechanical resistance.

Hence, the selected materials, available as films of different thicknesses are reported in Table 1. The monomers structures of the polymer materials are reported in Figure 1.

Flat-sheet membranes of (CA), (PDMS) and (FEP) are supplied by Goodfellow SARL. Films of Teflon $\circledast$ AF $2400(0.0016 ", \sim 40 \mu \mathrm{m})$ are purchased from Biogeneral and films of Nafion from Ion Power Inc.

It has to be noted that in order to compare the results of differents polymers materials, the experiments are performed with the same membrane thickness: $50 \mu \mathrm{m}$. Besides, it has to be noticed that FEP material was only used to understand the permability influence on the membrane fouling localization. Thus some analytical results and experiments reported below do not include this material.

\section{Characterization}

The membrane properties are investigated before and after membrane crystallization experiments by several measurements:

i. The contact angle and the surface tension are measured with a goniometer DSA10 (Krüss). Dioodomethane is used, as the non-polar liquid, to measure 
the surface tension. To achieve the analysis, samples are previously dried in a dessicator for a day in order to avoid residual moisture which would impact the contact angle measurement. For native membranes, the films are washed with deionized water (DI water) then dried in a dessicator for a day.

ii. The surface and the crystal morphology are imaged using Scanning Electron Microscopy (SEM). The analyses are performed with a FEI Quanta 250 FEG microscope at the "Centre Technologique des Microstructures" (CT $\mu)$ at the University of Lyon (Villeurbanne, France). The sample is dropped off on a flat steel holder before being coated under vacuum by cathodic sputtering with copper. Then, the samples were observed by SEM under an accelerating voltage of $15 \mathrm{kV}$.

iii. The mechanical properties are investigated on samples shaped with a reduced section, using ElectroPulsTM E10000 (INSTRON ${ }^{\circledR}$ ) in stretched mode. The shear stress rate is fixed for each type of material at $10 \mu \mathrm{m} . \mathrm{s}^{-1}$ for brittle materials and at $40 \mu \mathrm{m} . \mathrm{s}^{-1}$ for the flexible ones. It is kept constant until breaking of the material happened. The given stress-strain curves are then analyzed to determine the tensile strength and the elongation at break.

iv. Zeta potential measurements are performed using SurPASS Electro-kinetic Analyzer (Anton-Paar). To obtain the zeta potential of flat surfaces, an adjustable Gap Cell (Length $=20 \mathrm{~mm}$, Width $=10 \mathrm{~mm}$ ) is used. Measurements

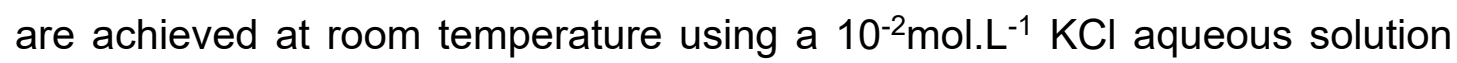
with a corresponding $\mathrm{pH}$ at 8.64. The gap is adjusted approximately to $100 \mu \mathrm{m}$ and the target pressure is at $500 \mathrm{mbar}$. The determination of the Zeta potentials from the streaming potential measurements is done using the Fairbrother-Mastin (FM) method in the Surpass VisioLab, excepted for Nafion membranes where the Helmholt-Smoluchowski approach (HS) using streaming current values is preferred.

\section{Experimental setup}

Experiments are conducted in diffusion cell, specially designed for the study and inspired from Franz cells (cf. Figure 2). Its design consists of two glass compartments of $10 \mathrm{~mL}$ each, the flat sheet membrane is placed in-between and the ensemble is maintained thanks to a clamping support. The inner diameter of each compartment is $20.4 \mathrm{~mm}$. Thus, the effective surface area of membrane placed in-between is 
$3.27 \mathrm{~cm}^{2}$. With theses dimensions, the mass transfer is supposed to occur only between the compartments because of the relative small membrane thickness (i.e with a film thickness of $50 \mu \mathrm{m}$, the corresponding surrounding surface area is $3.20 \mathrm{~cm}^{2}$ which is less than $1 \%$ of the effective surface area).

The diffusion cell and its support are then placed in a thermostated bath with a set temperature of $20^{\circ} \mathrm{C}$ (cf. Figure 2). Experiment are performed under a strict diffusion regime and no stirrer is used and there is no temperature gradient which could generate convection.

\section{Operating conditions}

The day before the experiment, the membranes studied are rinsed with DI water and dried in a dessicator during $24 \mathrm{~h}$.

A fresh aqueous solution of barium is prepared prior to the experiment by diluting $1 \mathrm{~g}$ of barium hydroxide $\left(\mathrm{Ba}(\mathrm{OH})_{2} .8 \mathrm{H}_{2} \mathrm{O}\right.$, Sigma-Aldrich, purity $\left.\geq 98 \%\right)$ into $100 \mathrm{~mL}$ of $\mathrm{DI}$ water. Before been transferred in the diffusion cell, the solution is filtered (Regenerated cellulose syringe filter of $0.45 \mu \mathrm{m}$ pore size $25 \mathrm{~mm}$ diameter Clearline) to remove any solid particles formed from residual level of $\mathrm{CO}_{2}$ in DI water. The clear solution thus obtained is named the mother solution. The real concentration of barium, in the mother solution, is then estimated at $2.9910^{-2}+/ .1 .06 .10^{-4} \mathrm{~mol}^{-\mathrm{L}^{-1}}$. In this case, the $\mathrm{CO}_{2}$ concentration required to start the precipitation of $\mathrm{BaCO}_{3}$ has to be around $8.0510^{-8} \mathrm{~mol} / \mathrm{L}$. This value is very low compare to the $\mathrm{CO}_{2}$ solubility in water (3.35 $10^{-2}$ at $298 \mathrm{~K}$, according to Henry's law). Thus the precipitation reaction is assumed to be instantaneous.

The membrane is then set on the liquid compartment. Special attention is paid to the positioning of the membrane in order to avoid the wetting of the side which will be in contact with the gas phase. The second compartment (with the two necks) is installed on the membrane and the ensemble is maintained together thanks to a clamping support (cf. Figure 2). Finally, the gas phase is connected to the necks and the two compartments are plunged in a thermostated bath at $20^{\circ} \mathrm{C}$ (cf. Figure 2). The $\mathrm{CO}_{2}$ gas flowrate $\left(\mathrm{CO}_{2}\right.$, Air-Liquid, purity $\left.>99.9 \%\right)$ is controlled by a mass flow meter (Brook SLA 5850). To promote the $\mathrm{CO}_{2}$ mass transfer from the gas phase to the liquid phase, a slight excessive pressure of $30 \mathrm{mbar}$ is imposed in the gas 
compartment thanks to a micro valve. The inlet and the outlet flows of $\mathrm{CO}_{2}$ are measured with a bubble flow meter thanks to a by-pass.

Each experiment is performed during $2 \mathrm{~h}$. At the end of the experiment, the gas flow is stopped and the membrane is retrieved and put in a dessicator until it is dried. The liquid phase is filtered with a $1.2 \mu \mathrm{m}$ removal filter (Mixed cellulose esters membranes RAWP025001, MerckMillipore) which is then also put in a dessicator for drying. The filtrate is bubbled with $\mathrm{CO}_{2}$ at $100 \mathrm{~mL} \cdot \mathrm{min}^{-1}$ during $1 \mathrm{~h}$ to precipitate the remaining barium, then the solution is let to dry during one night. Once upon that the membrane, the filters and the liquid compartment are totally dried (at least 2 days after the experiment), they are weighted and the characterization measurements are achieved.

\section{THEORY}

\section{Mass transport in dense membrane}

This development will be used to estimate the theoretical mass of solid that can be expected during the experiment (see nexts parts). It is usually assumed that the mass transfer mechanism in a dense polymer material follow the sorption-diffusion theory described by the following three successive stages (cf. Figure 3$)^{39}$ :

1. Adsorption of the permeant molecules on the membrane surface (feeding side)

2. Diffusion of the molecules throughout the membrane thickness

3. Desorption of the molecules of the opposite membrane surface (permeate side)

It is based on the following assumption: local equilirium conditions on the two sides of the membrane is accepted. Thus, the steady-state mass transfer follows a strict diffusion mechanism and is expressed by the first Fick's law:

$$
J_{i}=-D \frac{d C_{i}}{d x}
$$

With $\mathrm{Ji}_{\mathrm{i}}$ the flux by diffusion mechanism only $\left(\mathrm{mol} \cdot \mathrm{m}^{-2} \cdot \mathrm{s}^{-1}\right), \mathrm{D}$ the diffusion coefficient in the membrane $\left(\mathrm{m}^{2} . \mathrm{s}^{-1}\right), \mathrm{C}_{\mathrm{i}}$ the concentration in the membrane $\left(\mathrm{mol}^{-3} \mathrm{~m}^{-3}\right)$ and $\mathrm{x}$ the distance covered by the solute in the membrane thickness $(\mathrm{m})$.

Thus, the rate of the molecule displacements within the polymer matrix is proportional to the concentration gradient considered as the driving force. The 
mathematical description of the continuous flux is achieved by using an equilibrium equation between the solute in the gas phase and its solubility in the polymer according to Henry's law ${ }^{40}$ :

$$
C_{i}=S_{O} * P_{i}
$$

With $C$ the solute concentration in the membrane $\left(\mathrm{mol} . \mathrm{m}^{-3}\right)$, So the sorption coefficient in the membrane $\left(\mathrm{mol} \cdot \mathrm{m}^{-3} \cdot \mathrm{Pa}^{-1}\right), \mathrm{P}$ the partial pressure of the solute in the phase surrounding the membrane $(\mathrm{Pa})$.

Implementing this relation in equation (1) by assuming that So and $D$ are independent of pressure, gives the following well-known definition of the permability coefficient, Perm (mol.m. $\left.\mathrm{m}^{-2} \cdot \mathrm{Pa}^{-1} \cdot \mathrm{s}^{-1}\right)$ :

$$
P_{\text {erm }}=D * S_{O}
$$

The permeability is commonly expressed using the barrer unit: 1 barrer $=10^{-10}$ $\mathrm{cm}^{3}(\mathrm{STP}) \cdot \mathrm{cm} \cdot \mathrm{cm}^{-2} \cdot \mathrm{s}^{-1} \cdot \mathrm{cmHg} \mathrm{HH}^{-1}=3 \cdot 34710^{-16} \mathrm{~mol} \cdot \mathrm{m} \cdot \mathrm{m}^{-2} \cdot \mathrm{s}^{-1} \cdot \mathrm{Pa}^{-1} 41$.

Finally, the overall permeation process is dependent of both concentration gradient, sorption and diffusion coefficients. Actually, plasticizing effects, ageing, swelling, highly soluble molecules make it more difficult in reality to use this model as given here with all the given hypothesis. Other type of isothermal are usually required for numerous membrane materials, leading to more complex mathematical equations to be used in the modelisation of the permeant flux ${ }^{42}$.

\section{Estimation of the mass of $\mathrm{BaCO}_{3}(\mathrm{~s})$ crystals awaited}

The theoretical mass of $\mathrm{BaCO}_{3(\mathrm{~s})}$ crystals which can be obtained from one experience to another is calculated in two different ways, depending on the type of limitation encountered:

- When very few crystals are produced (CA, FEP), the $\mathrm{CO}_{2}$ permeabilities of the materials are used. Indeed, a great quantity of barium is still available in the liquid compartement after $2 \mathrm{~h}$ of experiment because the permeabilities of theses polymer materials are quite low. Thus, in this case the limitation in the $\mathrm{BaCO}_{3}(\mathrm{~s})$ production is of kinetic type.

- When a large amount of crystals is recovered (Nafion, PDMS, Teflon AF2400), the initial liquid composition stops the crystals production. Indeed, high permeabilies allowed lot of barium to react with the $\mathrm{CO}_{2}$. However, the 
appearance of the polarization effect at the membrane surface during the experiment is responsible for the very few remaining bariums to be consumed. Thus, in this case the limitation in the $\mathrm{BaCO}_{3(\mathrm{~s})}$ production is of physical type.

\section{- Theoretical mass of $\mathrm{BaCO}_{3(\mathrm{~s})}$ with a kinetic limitation}

According to the Fick diffusion law and the solution-diffusion model (all hypothesis of simplification considered) under steady state conditions, the transmembrane flux of carbon dioxide is given by:

$$
\mathrm{J}_{\mathrm{CO}_{2}}=-\mathrm{S} * \frac{\mathrm{Perm}_{\mathrm{eO}}}{\mathrm{z}} *\left(\mathrm{P}_{\mathrm{CO}_{2}, \mathrm{liq}}-\mathrm{P}_{\mathrm{CO}_{2}, \text { gaz }}\right)
$$

With JcO2 the flux of $\mathrm{CO}_{2}\left(\mathrm{~mol}^{-1} \mathrm{~s}^{-1}\right)$, Perm, $\mathrm{CO} 2$ the permeability coefficient of $\mathrm{CO}_{2}$ (mol.m. $\left.\mathrm{m}^{-2} \cdot \mathrm{s}^{-1} \cdot \mathrm{Pa}^{-1}\right)$, $S$ the membrane diffusion surface $\left(\mathrm{m}^{2}\right), Z$ the membrane thickness $(\mathrm{m}), \mathrm{P}_{\mathrm{CO}}$,liq the corresponding partial pressure of $\mathrm{CO}_{2}$ in the liquid phase $(\mathrm{Pa}), \mathrm{P}_{\mathrm{CO} 2 \text {,gaz }}$ the partial pressure of $\mathrm{CO}_{2}$ in the gas phase $(\mathrm{Pa})$.

The permeability coefficient and the membrane thickness are considered according to the data reported in Table 1. The diffusion surface is determined from the active surface area of the diffusion cell. The partial pressure of $\mathrm{CO}_{2}$ in the gas compartment is equivalent to the slight excessive pressure applied in the gas compartment. The partial pressure of $\mathrm{CO}_{2}$ in the liquid compartment is assumed to be at the thermodynamic equilibrium of the $\mathrm{BaCO}_{3}$ formation:

$$
\begin{gathered}
\mathrm{P}_{\mathrm{CO}_{2}, \mathrm{liq}}=\frac{\left[\mathrm{CO}_{3}^{2-}\right]_{\mathrm{eq}_{\mathrm{BaCO}}}}{\mathrm{H}_{(\mathrm{T})}} \\
{\left[\mathrm{CO}_{3}^{2-}\right]_{\mathrm{eq}, \mathrm{BaCO}_{3}}=\frac{\mathrm{Ks}_{\mathrm{BaCO}_{3}}}{\left[\mathrm{Ba}^{2+}\right]_{\mathrm{m}}}}
\end{gathered}
$$

With $\mathrm{P}_{\mathrm{CO} 2 \text {,liq }}$ the corresponding partial pressure of carbon dioxide in the liquid phase $(\mathrm{Pa}), \quad\left[\mathrm{CO}_{3}{ }^{2}\right.$ - eq, $\mathrm{BaCO} 3$ the $\mathrm{CO}_{2}$ concentration in the mother solution at the $\mathrm{BaCO}_{3}$ solubility equilibrium $\left(\mathrm{mol} \cdot \mathrm{m}^{-3}\right),\left[\mathrm{Ba}^{2+}\right] \mathrm{m}$ the barium concentration in the liquid phase $\left(\mathrm{mol} . \mathrm{m}^{-3}\right), \mathrm{Ks}_{\mathrm{BaCO}}$ the solubility product at $20^{\circ} \mathrm{C}$ of the $\mathrm{BaCO}_{3}$, at $2.5810^{-9} 43, \mathrm{H}_{(\mathrm{T})}$ the Henry's constant of in $\mathrm{CO}_{2}$ water at the given temperature $\mathrm{T}$, here $20^{\circ} \mathrm{C}\left(\mathrm{mol}^{-3} \mathrm{~m}^{-3} \cdot \mathrm{Pa}-\right.$ $1)$.

Since the barium concentration in this case is supposed almost constant, the initial concentration of barium in the liquid phase introduced in the liquid compartment is taken into account to make the calculations above at the $\mathrm{BaCO}_{3}$ equilibrium. The 
later is determined through a mass balance between $\mathrm{Ba}(\mathrm{OH})_{2} .8 \mathrm{H}_{2} \mathrm{O}$ weighted and $\mathrm{BaCO}_{3}$ crystals filtered during the mother solution preparation:

$$
\left[\mathrm{Ba}^{2+}\right]_{\mathrm{m}}=\frac{\frac{\mathrm{m}_{\mathrm{Ba}(\mathrm{OH})_{2} 8 \mathrm{BH}_{2} \mathrm{O}}}{\mathrm{Ma}_{\mathrm{BaH}} \mathrm{O}_{2} \mathrm{H}_{2} \mathrm{O}} \cdot \frac{\mathrm{m}_{\mathrm{BaCO}_{3}} \text { filter }}{\mathrm{M}_{\mathrm{BaCO}}}}{\mathrm{V}_{\mathrm{m}}}
$$

With $\left[\mathrm{Ba}^{2+}\right] \mathrm{m}$ the barium concentration in the liquid phase $\left(\mathrm{mol} \cdot \mathrm{m}^{-3}\right), \mathrm{m}_{\mathrm{Ba}(\mathrm{OH}) 2.8 \mathrm{H} 2 \mathrm{O}}$ the mass weighted for mother solution preparation $\left.(\mathrm{g}), \mathrm{MBa}_{\mathrm{O}} \mathrm{OH}\right) 2.8 \mathrm{H} 2 \mathrm{O}$ and $\mathrm{MBaCO}_{3}$ the molecular weights $\left(\mathrm{g}_{\mathrm{mol}}{ }^{-1}\right), \mathrm{m}_{\mathrm{BaCO}}$ the mass of crystals recovered at the filtration step of the mother solution preparation $(g), V_{m}$ the mother solution volume $\left(m^{3}\right)$.

The following thermodynamic correlation has been considered to estimate the Henry's constant ${ }^{44}$ :

$$
\ln (\mathrm{H})=-6,8346+\frac{1,281710^{4}}{\mathrm{~T}}-\frac{3,766810^{6}}{\mathrm{~T}^{2}}+\frac{2,99710^{8}}{\mathrm{~T}^{3}}
$$

With $\mathrm{T}$ the temperature $(\mathrm{K})$ and $\mathrm{H}$ the Henry's constant (MPa.molco2 ${ }^{-1} \cdot \mathrm{mol}_{\mathrm{H} 2 \mathrm{O}}$ ). Leading to Henry's constant at $20^{\circ} \mathrm{C}$ at $25.11 \mathrm{~atm} \cdot \mathrm{mol}^{-1}$ of $\mathrm{CO}_{2}$. LH2O.

Hence, the theoretical mass of $\mathrm{BaCO}_{3}$ which could be precipitated after $2 \mathrm{~h}$ of experiment when kinetic or permeability is limiting, is deduced:

$$
\mathrm{m}_{\mathrm{BaCO}_{3} \text {,theo } 1}=\mathrm{J}_{\mathrm{CO}_{2}} * \mathrm{t}_{\text {exp }} * \mathrm{M}_{\mathrm{BaCO}_{3}}
$$

With $\mathrm{JcO}_{\mathrm{c}}$ the flux of $\mathrm{CO}_{2}\left(\mathrm{~mol}^{-1} \mathrm{~s}^{-1}\right)$, texp the experiment duration (here $2 \mathrm{~h}$ ).

\section{- Theoretical mass of $\mathrm{BaCO}_{3(\mathrm{~s})}$ with a chemical composition limitation}

Knowing the actual barium concentration prepared, the maximum of $\mathrm{BaCO}_{3}$ crystals that would be attainable if all the $\mathrm{CO}_{2}$ needed was provided was calculated for $10 \mathrm{ml}$ of solution prepared:

$$
\begin{gathered}
m_{\mathrm{BaCO}_{3}, \text { theo } 2}=\left(\left[\mathrm{Ba}^{2+}\right]_{m}-\left[\mathrm{Ba}^{2+}\right]_{\text {solubility }}\right) * \mathrm{~V}_{\text {cell }} * \mathrm{M}_{\mathrm{BaCO}_{3}} \\
m_{\mathrm{BaCO}_{3}, \text { theo } 2}=\left(\left[\mathrm{Ba}^{2+}\right]_{m}-\frac{K S_{\mathrm{BaCO}_{3}}}{\left[\mathrm{CO}_{3}^{2-}\right]_{\text {max }}}\right) * V_{\text {cell }} * \mathrm{MaCO}_{3} \\
\mathrm{H}_{(\mathrm{T})}\left[\mathrm{CO}_{3}^{2-}\right]_{\max }=\mathrm{P}_{\mathrm{CO}_{2, \mathrm{gaz}}}
\end{gathered}
$$

With $\left[\mathrm{Ba}^{2+}\right.$ solubility the barium concentration at the $\mathrm{BaCO}_{3}$ solubility equilibrium with a liquid phase saturated in $\mathrm{CO}_{2}\left(\mathrm{~mol}^{-3} \mathrm{~m}^{-3}\right), \mathrm{V}_{\text {cell }}$ the volume of the diffusion cell liquid compartment, $10 \mathrm{ml}\left(\mathrm{m}^{-3}\right),\left[\mathrm{CO}_{3}{ }^{2-}\right] \max$ the $\mathrm{CO}_{2}$ concentration of a saturated solution (mol. $\mathrm{m}^{-3}, 3.9810^{-2} \mathrm{~mol}^{-\mathrm{L}^{-1}}$ with the given Henry's constant at $20^{\circ} \mathrm{C}$ ). 


\section{RESULTS AND DISCUSSION}

\section{Denses membranes properties - Mechanical resistance}

Most of the polymer material investigated in this study are glassy polymers. The polymer chains are quite stiff, consequently the formation of crystals between the polymer chains will modify their layout and thus the membrane properties. The mechanical resistance is a tool able to quantify the impact of the crystallization inside the membrane. Some studies are reported in the literature ${ }^{45,46}$, on a topic close to the aim of this work, about the influence of fillers on the relative tensile modulus.

The material stiffness is studied through the experimental measurement of the tensile strength and the elongation break. The tensile strength is determined at the highest stress of the strain-stress experimental curve, just before the material starts to break. At this point, the elongation break can be determined. From the results obtained and reported on Figure 4, three categories of material are recognizable.

At ambient temperature, the stiffness of PDMS, which is the only rubbery polymer studied, is the lowest compared to the stiffness of CA, FEP, Nafion, and Teflon AF 2400. Moreover, the tensile strength is below $5 \mathrm{MPa}$ but the extensibility is relatively good, above $100 \%$.

On the opposite, high tensile strengths are reported for the brittle glassy materials, i.e. CA (up to $60 \mathrm{MPa}$ ) and Teflon AF 2400 (up to $30 \mathrm{MPa}$ ) show relative high tensile strength but their extensibilitity is quite low, between $15-20 \%$. This kind of material is also characterized by a plastic plateau which corresponds to the starting point of the elastic-plastic transition.

FEP and Nafion are considered as intermediate glassy materials. Their stiffness is between the ones reported for the rubbery polymer and the brittle glassy polymers, but the strains at the breaking point are the highest, around $200 \%$.

Analysis have been repeated after soaking the membranes into DI water for $1 \mathrm{~h}$ or 24h. No influence of membrane humidification has been highlighted on the stressstrain values of both hydrophobic and hydrophilic polymer materials. 


\section{Impact of the operating conditions on the crystallization experiments}

\section{a) $\mathrm{CO}_{2}$ gas flowrate}

The study focuses on the role of the dense membrane on the crystallization location. Therefore, the experiments are performed with a saturated liquid phase, i.e saturated at the $\mathrm{BaCO}_{3(\mathrm{~s})}$ equilibrium. Three $\mathrm{CO}_{2}$ gas flowrates are investigated: 30, 60 and $120 \mathrm{~mL} \cdot \mathrm{min}^{-1}$, i.e. $1.5310^{-3}, 3.0610^{-3}$ and $6.1210^{-3} \mathrm{~m} . \mathrm{s}^{-1}$. Let us note that these are the flowrates across the gas compartment and not across the membrane. The total mass of $\mathrm{BaCO}_{3}$ crystals precipitated (on the membrane and in the diffusion cell) as a function of $\mathrm{CO}_{2}$ gas flowrate are reported in Table 2.

According to the set of experiments performed with the different polymer materials, $\mathrm{CO}_{2}$ gas flowrate seems to have no influence on the mass of $\mathrm{BaCO}_{3}$ precipitated. Same results are obtained both on the membrane and in the diffusion cell, whatever the $\mathrm{CO}_{2}$ gas flowrate used. Thus, the liquid phase is always saturated in $\mathrm{CO}_{2}$ during the experiment and this process parameter is not critical. A $30 \mathrm{~mL} \cdot \mathrm{min}^{-1} \mathrm{CO}_{2}$ gas flowrate is used in the rest of the study.

The results obtained on CA membrane are not relevant because this material is very sensitive to fouling as it will be demonstrated later.

\section{b) Membrane humidification}

The influence of the membrane humidification on the crystallization location is investigated. The aim is to get rid of the water diffusion in the membrane which occurs at the beginning of the experiment and could reduce the $\mathrm{CO}_{2}$ diffusion until reaching steady state of the solutes transferred through the membrane.

Thus, the dense membrane is soaked during $2 \mathrm{~h}$ in DI water before the experiments. Results obtained with soaked membranes, regarding the mass of $\mathrm{BaCO}_{3}$ crystals precipitated in the membrane and in the diffusion cell, are compared to those obtained with dried membranes and are reported on Figure 5.

Firstly, the results reflect that, as expected, no influence for hydrophobic materials is noticed throughout all experiments. The mass of $\mathrm{BaCO}_{3}$ recovered both on the membrane and in the diffusion cell are similar in both cases (dried and soaked membranes). 
Results obtained on Nafion lead to similar conclusion. Indeed, during the membrane preparation for experiment in the diffusion cell, it has been observed that the humidity level changed rapidly once the protective films are removed. Thus, no variation of the swelling ability is noticeable before and after soaking of this membrane. As expected, no changes in mass transfer and consequently no sensitive variation in the mass of $\mathrm{BaCO}_{3}$ recovered both on membrane and in diffusion cell are then noticeable between "dried" and soaked membranes (cf. Figure 5).

On the opposite, results obtained on CA membrane show a slight increase of the mass of $\mathrm{BaCO}_{3}$ recovered on the membrane once immerse into water. The biodegradability of the material is supposed to be responsible for changes in the polymer matrix and probably responsible for increasing the free volumes availability. Indeed, by soaking CA native membranes into DI water, a decrease of the membrane weight depending on the soaking time and membrane thicknesses has been observed (cf. Figure 6). It's the only type of membrane material of this study to have this particular property.

\section{Impact of the membrane properties on the crystallization location}

\section{a) Permeability and polymer state}

The potential scaling phenomenon of the studied membranes is investigated regarding the polymer structure. Result obtained on dried membranes are reported on Figure 7.

Results obtained on hydrophobic and highly permeable membranes, i.e. on PDMS and Teflon AF 2400, exhibit almost no change in weight before and after crystallization (cf. Figure 7). Only some scattered crystals on the membrane surface are noticeable on the SEM pictures (cf. Figure $8(a)$ ). $\mathrm{BaCO}_{3}$ crystals are only shaped in the liquid diffusion cell with no risk of intra-fouling, both for glassy (i.e. Teflon AF 2400) and rubbery (i.e. PDMS) polymer. Thereby, the polymer state of hydrophobic materials does not seem to do not have any effect on membrane fouling.

Makhloufi et al. ${ }^{14}$ reported opposite conclusion when he compared PDMS and Teflon AF 2400. However, contrary to their study where the reactants are two gases and thus are both able to permeate through the membrane, the present study focuses on the permeation of only one fo the reactants. Consequently, from the results obtained 
in this study and thoses reported by Makhloufi et al. ${ }^{14}$, it seems that the permeability of the reactants is one of the key parameters while the polymer structure has no influence on the crystallization location.

It has to be note that crystals fill around $60 \%$ of the cell volume forming a cloud. Consequently, the mass transfer resistance in the liquid phase increase and the mass of crystals recovered is lower than the mass of crystals expected.

Results obtained with FEP and CA show that the masses of the $\mathrm{BaCO}_{3}$ crystals recovered on the membrane are of the same order of magnitude than the masses recovered in the diffusion cell. Both materials have low $\mathrm{CO}_{2}$ permeabilities, respectively 13 and 23 barrer (cf. Table 1) but FEP is hydrophobic while CA is an hydrophilic polymer material. Both membranes present surface fouling (cf. Figure 8). Thus, the polymer wettability alone does not seem to have a critical influence on the crystallization location. Nevertheless, the surface tension of this polymer material (cf. Table 3) will certainly have a key role on the cleaning method that should be employed to improve the lifetime of the membrane. As presented on Figure 8, it has been easier to remove crystals from the FEP surface which is hydrophobic (tension surface $=16.61 \mathrm{mN} \cdot \mathrm{m}^{-1}$ ) than from the CA surface which is hydrophilic (surface tension $=45.97 \mathrm{mN} \cdot \mathrm{m}^{-1}$ ).

Moreover, the results obtained with FEP and CA membranes confirm the importance of the permeability parameter on the crystallization location. Hence, the permability of each reactant should be strongly different (at least one order of magnitude) to avoid inside fouling of the membrane and the permability of the transferred reactant $\left(\mathrm{CO}_{2}\right.$ in this study) should be high in order to promote crystallization in the bulk.

Results obtained on Nafion are similar to those obtained on CA and FEP: the mass of $\mathrm{BaCO}_{3}$ recovered on the membrane is of the same order of magnitude than in the diffusion cell. However, the amount of $\mathrm{BaCO}_{3}$ recovered are higher than those reported for CA and FEP. This is probably due to the increase of the $\mathrm{CO}_{2}$ permability of Nafion with its relative humidity $47-49$. At the beginning, the membrane is dried and has a $\mathrm{CO}_{2}$ permeability of the same magnitude than thoses of FEP and CA (cf. Table 1). Then with the increase of the membrane humidity, the permeability gets higher and is estimated at 319 Barrer at $30^{\circ} \mathrm{C}$ and $100 \%$ of relative humidity 50 . Consequently, the precipated crystal mass in the cell is higher than those observed 
with FEP and CA membranes. Indeed, contrary to the other polymer materials, barium ion can easily penetrate the polymer material what will favour the crystallization in and on the membrane surface. That is also the reason why the mass of crystals recovered is lower than the mass of $\mathrm{BaCO}_{3}$ expected.

\section{b) Surface behavior}

For hydrophilic materials (CA and Nafion), crystals agglomerate on the surface leading to a more or less thick layer of crystals at the end of experiments. On the contrary for hydrophobic materials (PDMS, Teflon AF 2400), scattered crystals are observed on the membrane surface (cf. Figure 9). Moreover, the adherence of $\mathrm{BaCO}_{3}$ crystals on the surface of hydrophobic materials does not seem critical.

In order to confirm this assumption, the influence of the membrane surface on fouling is investigated through the study of the influence of the surface tension and the contact angle. Results obtained with native membranes and after $2 \mathrm{~h}$ of experiments -without washing membranes surfaces- are reported in Table 3.

Results obtained show that there is almost no difference of the contact angle measurements achieved with PDMS and Teflon AF 2400 between the native membrane and the membrane after $2 \mathrm{~h}$ of experiments. However, the surface tension of PDMS membrane increases slightly after $2 \mathrm{~h}$ of experiments while the surface tension of Teflon AF 2400 remains constant. These results are corroborated by the scattered crystals of $\mathrm{BaCO}_{3}$ observed on the PDMS membrane surface while the Teflon AF 2400 membrane surface remained perfectly cleaned. But in both cases, the mass of crystal recovered in the cell diffusion (cf. Figure 7) is quite important. Hence, the PDMS membrane fouling is too small to significantly reduce the mass transfer through the membrane during the 2 hours of experiment.

On the contrary, the contact angle measurements and the surface tension achieved on hydrophilic polymer materials highlight a significant increase between the membrane before, i.e. the native membrane, and the membrane after $2 \mathrm{~h}$ of experiment. These results are corroborated by the observation of a thin layer of $\mathrm{BaCO}_{3}$ crystals on the membrane surface which leads to similar final surface tensions. The influence of this cake layer on the analytical results is assumed to be the same for FEP material. Indeed, a dense skin of crystal is also observed on this 
material after $2 \mathrm{~h}$ of experiments. Thus, similar final surface tension to those reported for CA and Nafion would have been expected: around 50-55 mN.m-1.

\section{c) Crystal shape}

The influence of the membrane permeability to $\mathrm{CO}_{2}$ on the shape of $\mathrm{BaCO}_{3}$ crystals recovered on the membrane surface are considered. SEM pictures of crystals recovered during experiments carried out with PDMS and CA membranes are taken and reported on Figure 10. As previously reported (cf. Figure 7), with the PDMS membrane, the crystals are mainly formed in the bulk and only few crystals could be observed on the surface while the opposite observation is done with CA membrane. Hence, Figure $10(a)$ reports $\mathrm{BaCO}_{3}$ crystals recovered in the bulk of the liquid phase with PDMS membrane and Figure 10(b) presents crystals recovered on the CA membrane surface.

During the experiments carried out on highly permeable hydrophobic membranes, i.e. PDSM and Teflon AF 2400, the $\mathrm{BaCO}_{3}$ crystallization can be observed by naked eyes in the liquid part of the diffusion cell: crystals first appear in the vicinity of the membrane surface, where the supersaturation is the highest, resulting in the formation of crystals blocks that time to time fall apart in the diffusion cell. But, even though a lot of crystals are produced during the experiments with this kind of membrane, very few crystals remain on the membrane surface (cf. Figure 7).

Hence, heterogeneous shapes and smaller crystals are obtained when a high permeable and hydrophobic membrane (cf. Figure 10 (a)), e.g. PDMS and Teflon AF 2400, whereas crystals recovered on the surface of hydrophilic membranes are bigger and needle-like (cf. Figure 10 (b)).

Figure 10 suggests that with a lower $\mathrm{CO}_{2}$ permeability the supersaturation ratio increases gradually which would induce a better control of the crystal growth and thus of the crystal size distribution.

\section{d) mechanical properties and zêta potential}

Measuring zeta potential is a widely used analytical method to monitor the membrane fouling. Indeed, by investing this membrane property scientis can get better insights on this critical phenomenon ${ }^{51}$. Several environnemental parameters such as, $\mathrm{pH}$ or cations/anions nature, valence and concentration, can easly affect the surface 
charges $^{52}$. Here the objective was to evaluate the zeta potential on native and cleaned membranes (after their use for crystallisation experiments), to see if any changes on their surface occurred. Thus a systematic protocol is applied using an

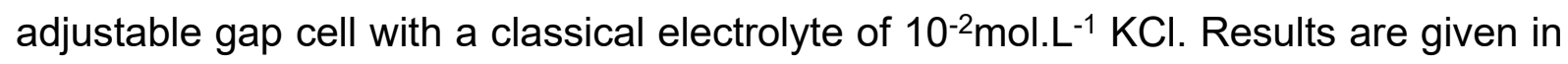
Table 4.

Only the Nafion membrane exhibits a tremendous change before and after membrane crystallisation. For Teflon AF2400 and PDMS membranes, the absence of evolution is expected since no crystals were deposited on their surface. For CA and FEP membranes, the absence of evolution shows that the deposit crystal layer, once removed by washing, did not affect their surface structure. On the contrary, the Nafion surface alteration supposes that either interactions betwenn $\mathrm{BaCO}_{3}$ crystals and the membrane surface occurred or that something happened within the polymer matrix consequently leading to changes on the membrane surface. In order to elucidate this last question, the evolution of the mechanical properties is investigated after $2 \mathrm{~h}$ of crystallization experiments. The main objective was to track fouling inside the membrane which may have induced a modification of the membrane properties. Results obtained are summarized in Table 5 and compared to those obtained on native membranes.

Table 5 exhibits that the tensile strength remains the same with the native membrane and the membrane after $2 \mathrm{~h}$ of crystallization experiment, whatever the membrane. As for potential measurements, the elongation break remains also constant except for Nafion for which a huge decrease is observed, the elongation break is divided by 6 after $2 \mathrm{~h}$ of crystallization experiment (cf. Figure 11).

The decrease of the elongation break of Nafion after $2 \mathrm{~h}$ of crystallization experiment suggests a change in the polymer matrix structure. This result has to be considered in relation to the results reported on Figure 7 which shows that a significant mass of $\mathrm{BaCO}_{3}$ crystals was recovered on the Nafion membrane.

Figure 12 reports SEM pictures of the surface of the gas-side membrane of Nafion and $\mathrm{CA}$. The SEM pictures clearly highlight that $\mathrm{BaCO}_{3}$ crystals are present on the Nafion surface in contact with the gas phase, while no crystals are observed on the CA surface. The observation allows assuming that barium ions were present inside 
and at the surface of the Nafion. This phenomenon is due to the ion-exchange property of the Nafion membrane. This result is consistent with previous measurements of Zêta potential and if elongation breakage which suggested, the presence of $\mathrm{BaCO}_{3}$ crystals inside the Nafion membrane. Hence, the measurement of the elongation break could be a simple tool, even if it is a destructive one, to track fouling inside dense membranes.

\section{e) Membrane thickness}

The effect of the membrane thickness on the crystallization location is only assessed on CA membranes. Three membrane thicknesses have been investigated: 35,50 and $100 \mu \mathrm{m}$. Results obtained with dried and soaked membranes are reported on Figure 13.

As expected, Figure 13 shows a decrease of the mass of $\mathrm{BaCO}_{3}$ crystals recovered on the membrane surface with the increase of the membrane thickness both on dried and on soaked membranes. This is explained by the decrease of the $\mathrm{CO}_{2}$ flux through the membrane (cf. au-dessus and Equation (9)).

Moreover, Figure 13 clearly exhibits that the masses of $\mathrm{BaCO}_{3}$ recovered on the soaked membranes are always higher than those collected on the dried membranes, whatever the membrane thickness. The phenomenon may highlight either the reach of the steady state or again the CA membrane degradation (cf. Figure 6). Indeed, on dried membranes, the first part of the experiment is dedicated to the competition of the mass transfer between $\mathrm{CO}_{2}$ crossing the membrane from the gas phase to the liquid phase and $\mathrm{H}_{2} \mathrm{O}$ going on the opposite direction. As the CA permeability to $\mathrm{H}_{2} \mathrm{O}$ is higher than to $\mathrm{CO}_{2}$, the first step of the experiment corresponds to the water saturation of the membrane. Once the membrane is saturated with water, the mass transfer of $\mathrm{CO}_{2}$ can start and the steady state is then reached. On soaked membranes, the first step is skipped and the $\mathrm{CO}_{2}$ mass transfer starts from the beginning of the experiment. 


\section{CONCLUSION}

In order to better understand fouling mechanisms and circumvent them, $\mathrm{BaCO}_{3}$ crystallization is investigated under different operating conditions with no hydrodynamic influences and using commercially available dense membranes. The selected polymers have been fully characterized in terms of thermal, mechanical, water affinity properties before and after the membrane crystallization.

Results obtained highlight that the polymer state, i.e. rubbery or glassy, has no influence on the crystallization location or on the fouling issue. This result is contrary to what was expected given what is reported in the literature. Hence, it clearly appears that the permeability is one of the parameter controlling the crystallization location. If a membrane contactor is used when two reactives species have close permeabilities then the crystallization will occur in the free volumes of the dense membrane. Otherwise, the crystallization will only take place in one side of the membrane contactor. Moreover, the permeability also favours surface fouling if it is too low, while the surface tension will favour the ability to clean the membrane easily.

Thus, permeability and surface tension are two key parameters to select carefully for a crystallization process using a membrane contactor.

The membrane thickness only impacts the $\mathrm{CO}_{2}$ flux through the membrane but does not seem to influence the crystallization location.

The elongation break measurement appear as a useful tool to track fouling inside the membrane.

Experiments in dynamic conditions, on short and on long time scales, have to be performed on membrane contactors in order to confirm these results.

\section{Nomenclature}

$\left[\mathrm{Ba}^{2+}\right]_{\mathrm{m}}$

$\left[\mathrm{Ba}^{2+}\right]$ solubility

$\mathrm{C}_{\mathrm{i}}$

$\left[\mathrm{CO}_{3}{ }^{2-}\right]_{\text {eq,BaCO3 }}$

$\left[\mathrm{CO}_{3}{ }^{2-}\right]_{\max }$

$\mathrm{D}$

$\mathrm{Ji}$

barium concentration in solution $\left[\mathrm{mol} \mathrm{m}^{-3}\right.$ ] barium concentration at the $\mathrm{BaCO}_{3}$ solubility $\left[\mathrm{mol} \mathrm{m}^{-3}\right]$ component i concentration in the membrane $\left[\mathrm{mol} \mathrm{m}^{-3}\right]$ $\mathrm{CO}_{2}$ concentration in solution at the $\mathrm{BaCO}_{3}$ solubility $\left[\mathrm{mol} \mathrm{m}^{-3}\right]$ $\mathrm{CO}_{2}$ concentration in a saturated solution [ $\mathrm{mol} \mathrm{m}^{-3}$ ] diffusion coefficient in the membrane $\left[\mathrm{m}^{2} \mathrm{~s}^{-1}\right]$ transmembrane flux of component i [mol m m$\left.~ m^{-2} \mathrm{~s}^{-1} \mathrm{~Pa}^{-1}\right]$ 


\begin{tabular}{|c|c|}
\hline $\mathrm{JCO}_{\mathrm{C}}$ & transmembrane flux of $\mathrm{CO}_{2}\left[\mathrm{~mol} \mathrm{~m} \mathrm{~m} \mathrm{~m}^{-2} \mathrm{~s}^{-1} \mathrm{~Pa}^{-1}\right]$ \\
\hline$H_{(T)}$ & Henry's constant of $\mathrm{CO}_{2}\left[\mathrm{~atm}\right.$ molco2$\left.{ }^{-1} \mathrm{LH}_{2} \mathrm{O}\right]$ \\
\hline $\mathrm{K}_{\mathrm{sBaCO}}$ & solubility product of $\mathrm{BaCO}_{3}\left[2.5810^{-9}\right]$ \\
\hline $\mathrm{mBaCO}_{\mathrm{B}}$ & mass of $\mathrm{BaCO}_{3}$ crystal with mother solution filtration [mg] \\
\hline $\mathrm{mBaCO}$, theo1 & theoretical mass of $\mathrm{BaCO}_{3}$ with kinetic limitation \\
\hline $\mathrm{mBaCO}$, theo2 & theoretical mass of $\mathrm{BaCO}_{3}$ with chemical limitation \\
\hline 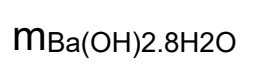 & mass of $\mathrm{Ba}(\mathrm{OH})_{2} 8 \mathrm{H}_{2} \mathrm{O}$ for mother solution preparation [mg] \\
\hline МвасO3 & molecular mass of $\mathrm{BaCO}_{3}\left[\mathrm{~g} \mathrm{~mol}^{-1}\right]$ \\
\hline $\mathrm{MBa}(\mathrm{OH}) 2.8 \mathrm{H} 2 \mathrm{O}$ & molecular mass of $\mathrm{Ba}(\mathrm{OH})_{2} 8 \mathrm{H}_{2} \mathrm{O}\left[\mathrm{g} \mathrm{mol}^{-1}\right]$ \\
\hline Perm & permeability data $\left[\mathrm{mol} \mathrm{m} \mathrm{m} \mathrm{m} \mathrm{s}^{-1} \mathrm{~Pa}^{-1}\right]$ \\
\hline Perm,CO2 & $\mathrm{CO}_{2}$ permeability $\left[\mathrm{mol} \mathrm{m} \mathrm{m}^{-2} \mathrm{~s}^{-1} \mathrm{~Pa}^{-1}\right]$ \\
\hline Pco2,liq & $\mathrm{CO}_{2}$ partial pressure in the liquid phase $[\mathrm{Pa}]$ \\
\hline$P_{c 02, g a z}$ & $\mathrm{CO}_{2}$ partial pressure in the gaz phase $[\mathrm{Pa}]$ \\
\hline $\mathrm{Pi}_{\mathrm{i}}$ & component I partial pressure $[\mathrm{Pa}]$ \\
\hline S & active surface in the diffusion cell $\left[\mathrm{m}^{2}\right]$ \\
\hline So & sorption coefficient in the membrane $\left[\mathrm{mol} \mathrm{m}^{-3} \mathrm{~Pa}^{-1}\right]$ \\
\hline texp & time of membrane crystallization experiment [s] \\
\hline $\operatorname{Tg}$ & glass transition temperature \\
\hline $\mathrm{V}_{\text {cell }}$ & diffusion cell volume [10 ml] \\
\hline$V_{m}$ & total volume of mother solution prepared [100 ml] \\
\hline$z$ & membrane thickness $[\mathrm{m}]$ \\
\hline
\end{tabular}

\section{ACKNOWLEDGMENT}

This study has been funded thanks to the ANR (Agence Nationale de la Recherche) grant ICARE (2016-2020).

\section{REFERENCES}

(1) Jongen, N.; Donnet, M.; Bowen, P.; Lemaître, J.; Hofmann, H.; Schenk, R.; Hofmann, C.; Aoun-Habbache, M.; Guillemet-Fritsch, S.; Sarrias, J.; et al. Development of a Continuous Segmented Flow Tubular Reactor and the "Scale-out" Concept - In Search of Perfect Powders. Chem. Eng. Technol. 2003, 26 (3), 303-305. https://doi.org/10.1002/ceat.200390046.

(2) Tavare, N. S. Micromixing Limits in an MSMPR Crystallizer. Chem. Eng. Technol. 1989, 12 (1), 1-11. https://doi.org/10.1002/ceat.270120102. 
(3) Drioli, E.; Di Profio, G.; Curcio, E. Progress in Membrane Crystallization. Curr. Opin. Chem. Eng. 2012, 1 (2), 178-182. https://doi.org/10.1016/j.coche.2012.03.005.

(4) Chabanon, E.; Mangin, D.; Charcosset, C. Membranes and Crystallization Processes: State of the Art and Prospects. J. Membr. Sci. 2016, 509, 57-67. https://doi.org/10.1016/j.memsci.2016.02.051.

(5) Curcio, E.; Criscuoli, A.; Drioli, E. Membrane Crystallizers. Ind. Eng. Chem. Res. 2001, 40 (12), 2679-2684. https://doi.org/10.1021/ie000906d.

(6) Profio, G. D.; Caridi, A.; Caliandro, R.; Guagliardi, A.; Curcio, E.; Drioli, E. Fine Dosage of Antisolvent in the Crystallization of L-Histidine: Effect on Polymorphism. Cryst. Growth Des. 2010, 10 (1), 449-455. https://doi.org/10.1021/cg901038g.

(7) Simone, E.; Othman, R.; Vladisavljević, G. T.; Nagy, Z. K. Preventing Crystal Agglomeration of Pharmaceutical Crystals Using Temperature Cycling and a Novel Membrane Crystallization Procedure for Seed Crystal Generation. Pharmaceutics 2018, 10 (1). https://doi.org/10.3390/pharmaceutics10010017.

(8) Zarkadas, D. M.; Sirkar, K. K. Antisolvent Crystallization in Porous Hollow Fiber Devices. Chem. Eng. Sci. 2006, 61 (15), 5030-5048. https://doi.org/10.1016/j.ces.2006.03.036.

(9) Kober, P. A. PERVAPORATION, PERSTILLATION AND PERCRYSTALLIZATION.1. J. Am. Chem. Soc. 1917, 39 (5), 944-948. https://doi.org/10.1021/ja02250a011.

(10) Azoury, R.; Garside, J.; Robertson, W. G. Crystallization Processes Using Reverse Osmosis. J. Cryst. Growth 1986, 79 (1-3), 654-657. https://doi.org/10.1016/0022-0248(86)90533-6.

(11) Drioli, E.; Wu, Y. Membrane Distillation: An Experimental Study. Desalination 1985, 53 (1), 339-346. https://doi.org/10.1016/0011-9164(85)85071-2.

(12) Lawson, K. W.; Lloyd, D. R. Membrane Distillation. J. Membr. Sci. 1997, 124 (1), 1-25. https://doi.org/10.1016/S0376-7388(96)00236-0.

(13) Cabassud, C.; Wirth, D. Membrane Distillation for Water Desalination: How to Chose an Appropriate Membrane? Desalination 2003, 157 (1), 307-314. https://doi.org/10.1016/S0011-9164(03)00410-7.

(14) Makhloufi, C.; Lasseuguette, E.; Remigy, J. C.; Belaissaoui, B.; Roizard, D.; Favre, E. Ammonia Based CO2 Capture Process Using Hollow Fiber Membrane Contactors. J. Membr. Sci. 2014, 455, 236-246. https://doi.org/10.1016/j.memsci.2013.12.063.

(15) Kieffer, R.; Mangin, D.; Puel, F.; Charcosset, C. Precipitation of Barium Sulphate in a Hollow Fiber Membrane Contactor, Part I: Investigation of Particulate Fouling. Chem. Eng. Sci. 2009, 64 (8), 1759-1767. https://doi.org/10.1016/j.ces.2009.01.011.

(16) Gabelman, A.; Hwang, S.-T. Hollow Fiber Membrane Contactors. J. Membr. Sci. 1999, 159 (1-2), 61-106. https://doi.org/10.1016/S0376-7388(99)00040-X.

(17) Mullin, J. W. Crystallization; Butterworth \& Co Publishers Ltd, 1972.

(18) Di Profio, G.; Stabile, C.; Caridi, A.; Curcio, E.; Drioli, E. Antisolvent Membrane Crystallization of Pharmaceutical Compounds. J. Pharm. Sci. 2009, 98 (12), 4902-4913. https://doi.org/10.1002/jps.21785.

(19) Polino, M.; Carvalho, A. L.; Juknaitè, L.; Portugal, C. A. M.; Coelhoso, I. M.; Romão, M. J.; Crespo, J. G. Ion-Exchange Membranes for Stable Derivatization of Protein Crystals. Cryst. Growth Des. 2017. https://doi.org/10.1021/acs.cgd.7b00315. 
(20) Khayet, M. Desalination by Membrane Distillation. In Water and wastewater tratment technologies.

(21) Drioli, E.; Ali, A.; Macedonio, F. Membrane Distillation: Recent Developments and Perspectives. Desalination 2015, 356, 56-84. https://doi.org/10.1016/j.desal.2014.10.028.

(22) Gryta, M.; Tomaszewska, M.; Grzechulska, J.; Morawski, A. W. Membrane Distillation of $\mathrm{NaCl}$ Solution Containing Natural Organic Matter. J. Membr. Sci. 2001, 181 (2), 279-287. https://doi.org/10.1016/S0376-7388(00)00582-2.

(23) Lawson, K. W.; Lloyd, D. R. Membrane Distillation. J. Membr. Sci. 1997, 124 (1), 1-25. https://doi.org/10.1016/S0376-7388(96)00236-0.

(24) Favre, E.; Svendsen, H. F. Membrane Contactors for Intensified PostCombustion Carbon Dioxide Capture by Gas-Liquid Absorption Processes. J. Membr. Sci. 2012, 407-408, https://doi.org/10.1016/j.memsci.2012.03.019.

(25) Li, J.-L.; Chen, B.-H. Review of CO2 Absorption Using Chemical Solvents in Hollow Fiber Membrane Contactors. Sep. Purif. Technol. 2005, 41 (2), 109_ 122. https://doi.org/10.1016/j.seppur.2004.09.008.

(26) Zhang, M.; Hou, D.; She, Q.; Tang, C. Y. Gypsum Scaling in Pressure Retarded Osmosis: Experiments, Mechanisms and Implications. Water Res. 2014, 48, 387-395. https://doi.org/10.1016/j.watres.2013.09.051.

(27) Gryta, M. Fouling in Direct Contact Membrane Distillation Process. J. Membr. Sci. 2008, 325 (1), 383-394. https://doi.org/10.1016/j.memsci.2008.08.001.

(28) Fortunato, L.; Qamar, A.; Wang, Y.; Jeong, S.; Leiknes, T. In-Situ Assessment of Biofilm Formation in Submerged Membrane System Using Optical Coherence Tomography and Computational Fluid Dynamics. J. Membr. Sci. 2017, 521, 84-94. https://doi.org/10.1016/j.memsci.2016.09.004.

(29) Xie, M.; Gray, S. R. Silica Scaling in Forward Osmosis: From Solution to Membrane Interface. Water Res. 2017, 108, 232-239. https://doi.org/10.1016/j.watres.2016.10.082.

(30) Xie, M.; Gray, S. R. Gypsum Scaling in Forward Osmosis: Role of Membrane Surface Chemistry. J. Membr. Sci. 2016, 513, 250-259. https://doi.org/10.1016/j.memsci.2016.04.022.

(31) Wu, J.; Contreras, A. E.; Li, Q. Studying the Impact of RO Membrane Surface Functional Groups on Alginate Fouling in Seawater Desalination. J. Membr. Sci. 2014, 458, 120-127. https://doi.org/10.1016/j.memsci.2014.01.056.

(32) Kim, J.; Kwon, H.; Lee, S.; Lee, S.; Hong, S. Membrane Distillation (MD) Integrated with Crystallization (MDC) for Shale Gas Produced Water (SGPW) Treatment. Desalination 2017, 403, 172-178. https://doi.org/10.1016/j.desal.2016.07.045.

(33) Xiao, Z.; Zheng, R.; Liu, Y.; He, H.; Yuan, X.; Ji, Y.; Li, D.; Yin, H.; Zhang, Y.; $\mathrm{Li}, \mathrm{X} . \mathrm{M}$.; et al. Slippery for Scaling Resistance in Membrane Distillation: A Novel Porous Micropillared Superhydrophobic Surface. Water Res. 2019, 155, 152-161. https://doi.org/10.1016/j.watres.2019.01.036.

(34) Karanikola, V.; Boo, C.; Rolf, J.; Elimelech, M. Engineered Slippery Surface to Mitigate Gypsum Scaling in Membrane Distillation for Treatment of Hypersaline Industrial Wastewaters. Environ. Sci. Technol. 2018, 52 (24), 14362-14370. https://doi.org/10.1021/acs.est.8b04836.

(35) Nguyen, D. H. Etude des propriétés électriques des élastomères silicones utilisés pour l'isolation électrique. PhD Thesis, Université Joseph-Fourier Grenoble I, 2005. 
(36) Mejia, D.; Castel, C.; Lemaitre, C.; Favre, E. Membrane Distillation (MD) Processes for Water Desalination Applications. Can Dense Selfstanding Membranes Compete with Microporous Hydrophobic Materials? Chem. Eng. Sci. 2018, 188. https://doi.org/10.1016/j.ces.2018.05.025.

(37) McLeod, A.; Buzatu, P.; Autin, B. Controlling Shell-Side Crystal Nucleation in a Gas-Liquid Membrane Contactor for Simultaneous Ammonium Bicarbonate Recovery and Biogas Upgrading. J. Membr. Sci. 2014, 473, 146-156.

(38) Di Profio, G.; Curcio, E.; Drioli, E. Supersaturation Control and Heterogeneous Nucleation in Membrane Crystallizers: Facts and Perspectives. Ind. Eng. Chem. Res. 2010, 49 (23), 11878-11889. https://doi.org/10.1021/ie100418z.

(39) Basile, A.; Figoli, A.; Khayet, M. Pervaporation, Vapour Permeation and Membrane Distillation - 1st Edition; Woodhead Publishing, 2015.

(40) Paul, D. R. Gas Sorption and Transport in Glassy Polymers. Berichte Bunsenges. Für Phys. Chem. 1979, 83 (4), 294-302. https://doi.org/10.1002/bbpc.19790830403.

(41) Favre, E. Polymeric Membranes for Gas Separation. In Comprehensive Membrane Science and Engineering; Oxford: Academic Press.; Elsevier Science, 2010; Vol. 2, pp 155-212. http://dx.doi.org/10.1016/B978-0-08093250-7.00020-7.

(42) Drioli, E.; Giorno, L.; Fontananova, E. Comprehensive Membrane Science and Engineering - 2nd Edition; Elsevier Science; Elsevier Science, 2017.

(43) Salvatori, F.; Muhr, H.; Plasari, E.; Bossoutrot, J.-M. Determination of Nucleation and Crystal Growth Kinetics of Barium Carbonate. Powder Technol. 2002, 128 (2-3), 114-123. https://doi.org/10.1016/S0032-5910(02)00184-5.

(44) Carroll, J. J.; Slupsky, J. D.; Mather, A. E. The Solubility of Carbon Dioxide in Water at Low Pressure. J. Phys. Chem. Ref. Data 1991, 20 (6), 1201-1209. https://doi.org/10.1063/1.555900.

(45) Bigg, D. M. Mechanical Properties of Particulate Filled Polymers. Polym. Compos. 1987, 8 (2), 115-122. https://doi.org/10.1002/pc.750080208.

(46) Grellmann, W.; Seidler, S.; Anderson, P. Polymer Testing, 2nd Edition.; Hanser, 2014.

(47) Ma, S.; Odgaard, M.; Skou, E. Carbon Dioxide Permeability of Proton Exchange Membranes for Fuel Cells. Solid State Ion. 2005, 176 (39), 29232927. https://doi.org/10.1016/j.ssi.2005.09.024.

(48) Hwang, G. S.; Parkinson, D. Y.; Kusoglu, A.; MacDowell, A. A.; Weber, A. Z. Understanding Water Uptake and Transport in Nafion Using X-Ray Microtomography. ACS Macro Lett. 2013, 2 (4), 288-291. https://doi.org/10.1021/mz300651a.

(49) Izak, P.; Hovorka, S.; Bartovsky, T.; Bartovska, L.; Crespo, J. G. Swelling of Polymeric Membranes in Room Temperature lonic Liquids. J. Membr. Sci. 2007, 296 (1), 131-138. https://doi.org/10.1016/j.memsci.2007.03.022.

(50) Ren, X.; Myles, T. D.; Grew, K. N.; Chiu, W. K. S. Carbon Dioxide Transport in Nafion 1100 EW Membrane and in a Direct Methanol Fuel Cell. J. Electrochem. Soc. 2015, 162 (10), F1221-F1230. https://doi.org/10.1149/2.0711510jes.

(51) Breite, D.; Went, M.; Prager, A.; Schulze, A. The Critical Zeta Potential of Polymer Membranes: How Electrolytes Impact Membrane Fouling. RSC Adv. 2016, 6 (100), 98180-98189. https://doi.org/10.1039/C6RA19239D.

(52) Xie, H.; Saito, T.; Hickner, M. A. Zeta Potential of Ion-Conductive Membranes by Streaming Current Measurements. Langmuir 2011, 27 (8), 4721-4727. https://doi.org/10.1021/la105120f. 
(53) Nagy, E. 1 - On Mass Transport Through a Membrane Layer. In Basic Equations of the Mass Transport through a Membrane Layer; Nagy, E., Ed.; Elsevier: Oxford, 2012; pp 1-34. https://doi.org/10.1016/B978-0-12-4160255.00001-6. 
TABLE 1

Dense membranes selected in the study

\begin{tabular}{|c|c|c|c|c|c|}
\hline Membrane material & $\begin{array}{c}\text { Polymer } \\
\text { condition }\end{array}$ & $\begin{array}{c}\text { Polymer } \\
\text { state at } \\
20^{\circ} \mathrm{C}\end{array}$ & $\begin{array}{c}\mathrm{H}_{2} \mathrm{O} \\
\text { Permeability } \\
(\text { barrer })\end{array}$ & $\begin{array}{c}\mathrm{CO}_{2} \\
\text { permeability } \\
(\text { barrer })\end{array}$ & $\begin{array}{c}\text { Thickness } \\
(\mu \mathrm{m})\end{array}$ \\
\hline $\begin{array}{c}\text { Cellulose Acetate } \\
(\mathrm{CA})\end{array}$ & Hydrophilic & Glassy & $5333-6667^{(\mathrm{a})}$ & $23^{(\mathrm{a})}$ & $35-50-100$ \\
\hline Nafion & Hydrophilic & Glassy & $60^{\text {(d) }}(\mathrm{dry})$ & $4.75^{\text {(c) }}(\mathrm{dry})$ & 50 \\
\hline Teflon AF 2400 & Hydrophobic & Glassy & $4026^{(\mathrm{b})}$ & $2800^{\text {(b) }}$ & $\begin{array}{c}\approx 40 \\
\left(0.0016^{\prime \prime}\right)\end{array}$ \\
\hline $\begin{array}{c}\text { Fluorinated Ethylene } \\
\text { Propylene (FEP) }\end{array}$ & Hydrophobic & Glassy & $17^{(\mathrm{a})}$ & $13^{\text {(a) }}$ & 50 \\
\hline $\begin{array}{c}\text { Polydimethylsiloxane } \\
\text { (PDMS) }\end{array}$ & Hydrophobic & Rubbery & $42667^{(\mathrm{a})}$ & $333^{(\mathrm{a})}$ & 50 \\
\hline
\end{tabular}

(a) Datas from supplier: GoodFellow

(b) Datas from supplier : Biogeneral

(c) I. Pinnau et L. G. Toy, « Gas and vapor transport properties of amorphous perfluorinated copolymer membranes based on 2,2-bistrifluoromethyl-4,5-difluoro-1,3-dioxole/tetrafluoroethylene », J. Membr. Sci., no 109, p. 125-133, 1996

(d) Qiongjuan D. et al., “Transport of liquid water through Nafion membranes”, J. Membre. Sci., n³92-393, p. 88-94, 2012 


\section{TABLE 2}

Mass of $\mathrm{BaCO}_{3}$ crystals precipitated (on the membrane and in the diffusion cell) as a function of the $\mathrm{CO}_{2}$ gas flowrate

\begin{tabular}{|c|c|c|c|}
\hline Polymer material & $1.5310^{-3} \mathrm{~m} . \mathrm{s}^{-1}$ & $\begin{array}{c}\mathrm{CO}_{2} \text { velocity } \\
3.0610^{-3} \mathrm{~m} . \mathrm{s}^{-1}\end{array}$ & $6.1210^{-3} \mathrm{~m} \cdot \mathrm{s}^{-1}$ \\
\hline CA & $5.1 \mathrm{mg}+/ .1 .8$ & $2.7 \mathrm{mg}+/ .0 .4$ & $3.8 \mathrm{mg}+0.9$ \\
\hline Nafion & $11.7 \mathrm{mg}+/ .1 .0$ & - & $12.2 \mathrm{mg}+/ .1 .3$ \\
\hline PDMS & $45.9 \mathrm{mg}+/ .3 .4$ & $51.9 \mathrm{mg}+5.0$ & $49.1 \mathrm{mg}+/ .1 .9$ \\
\hline Teflon AF 2400 & $45.6 \mathrm{mg}+1.1 .9$ & - & $48.9 \mathrm{mg}+/ .1 .2$ \\
\hline
\end{tabular}




\section{TABLE 3}

Contact angle measurement with water and surface tension before and after crystallization experiments

\begin{tabular}{|c|c|c|c|c|}
\hline & \multicolumn{2}{|c|}{ Native membrane } & \multicolumn{2}{|c|}{$\begin{array}{c}\text { After } 2 \mathrm{~h} \text { of crystallization } \\
\text { experiment }\end{array}$} \\
\hline & $\begin{array}{l}\text { Contact angle } \\
\text { with water }\left(\left(^{\circ}\right)\right.\end{array}$ & $\begin{array}{l}\text { Surface } \\
\text { tension } \\
\left(\mathrm{mN} \cdot \mathrm{m}^{-1}\right)\end{array}$ & $\begin{array}{l}\text { Contact angle } \\
\text { with water }\left({ }^{\circ}\right)\end{array}$ & $\begin{array}{c}\text { Surface } \\
\text { tension } \\
\left(\mathrm{mN} \cdot \mathrm{m}^{-1}\right)\end{array}$ \\
\hline CA & $77.63+/ .3 .97$ & $45.97+3.44$ & $127.3+15.9$ & $56.9+4.32$ \\
\hline Nafion & $94.81+/ .0 .33$ & $22.68+1.2 .27$ & $100.9+14.5$ & $51.8+1.32$ \\
\hline PDMS & $116.29+/ .0 .29$ & $15.82+0.78$ & $118.0+/ .4 .9$ & $22.0+/ .2 .69$ \\
\hline Teflon AF 2400 & $113.40+/ .3 .01$ & $10.90+/ .2 .81$ & $114.3+/ .2 .2$ & $10.80+0.41$ \\
\hline FEP & $107.71+/ .0 .90$ & $16.61+/ .0 .41$ & - & - \\
\hline
\end{tabular}




\section{TABLE 4}

Zeta potential values before/after membrane crystallization

\begin{tabular}{|c|c|c|}
\hline & Native membrane & $\begin{array}{c}\text { Cleaned membrane } \\
\text { (after 2h of crystallization } \\
\text { experiment) }\end{array}$ \\
\hline AC & $-27 \% .1 \mathrm{mV}$ & $-23 \% .3 \mathrm{mV}$ \\
\hline Nafion & $-57 \% .18 \mathrm{mV}$ & $-14 \% .8 \mathrm{mV}$ \\
\hline Teflon AF2400 & $-43+.2 \mathrm{mV}$ & $-42+\% .8 \mathrm{mV}$ \\
\hline FEP & $-44 \% .2 \mathrm{mV}$ & $-55 \% .4 \mathrm{mV}$ \\
\hline PDMS & $-40 \% .8 \mathrm{mV}$ & $-41+5 \mathrm{mV}$ \\
\hline
\end{tabular}




\section{TABLE 5}

\section{Mechanical values before/after membrane crystallization}

\begin{tabular}{|c|c|c|c|c|}
\cline { 2 - 5 } \multicolumn{1}{c|}{} & \multicolumn{2}{c|}{ Native membrane } & \multicolumn{2}{c|}{$\begin{array}{c}\text { Membrane after } 2 \mathrm{~h} \text { of } \\
\text { crystallization experiment }\end{array}$} \\
\cline { 2 - 5 } & $\begin{array}{c}\text { Tensile } \\
\text { strength } \\
(\mathrm{MPa})\end{array}$ & $\begin{array}{c}\text { Elongation } \\
\text { break (\%) }\end{array}$ & $\begin{array}{c}\text { Tensile } \\
\text { strength } \\
(\mathrm{MPa})\end{array}$ & $\begin{array}{c}\text { Elongation } \\
\text { break }(\%)\end{array}$ \\
\hline CA & $58 \% .5$ & $18 \% .6$ & $61 \% .9$ & $17 \% .8$ \\
\hline Nafion & $23 \% .2$ & $213 \% .35$ & $29 \% .4$ & $35 \% .5$ \\
\hline PDMS & $3 \% .1$ & $196 \% .47$ & $2 \% \% .1$ & $203 \% .25$ \\
\hline Teflon AF 2400 & $41 \% .12$ & $12 \% .3$ & $46 \% .4$ & $18 \% .12$ \\
\hline
\end{tabular}

